\title{
Diffusion of PV in Japan and Germany-Role of Market-Based Incentive and Research and Development (R\&D) Investment
}

\author{
Sanjeeda Chowdhury and Ushio Sumita*
}

\author{
Graduate School of System and Information Engineering, Social System and Management, Tsukuba \\ University, 1-1-1, Tennodai, Tsukuba, Ibaraki, Japan
}

\begin{abstract}
The goals of increasing the use of PV energy face significant obstacles. Regulatory requirements can be used to mandate the adoption of renewable energy, but market-based incentive mechanisms can also achieve the same results by inducing voluntary behavior from stakeholders. Variations in terms of both design and implementation of market-based incentives can have meaningful effects on the outcomes of incentive programs. We examine Japan and Germany in which PV energy accounts for a relatively high portion of total net electricity energy consumption. Germany FITs were originally linked to the spot electricity price, but a fixed tariff was adopted in 2000, and revised in 2004. A grant program also funds a portion of construction costs for new PV systems. The country has experienced rapid uptake of renewables over the past decade, making it a world leader in solar PV at the end of 2008. The purpose of this study is to analyze the PV diffusion in Japan and Germany during 1990-2011. Germany chooses an effective market-based incentive mechanism which is long term and more generous than Japanese incentive program. The termination of incentive policy is the main blocking factor of the decline of PV market in Japan.
\end{abstract}

Keywords: Photovoltaic, PV, Market-based Incentive, Japan, Germany, Renewable energy.

\section{INTRODUCTION}

Photovoltaic (PV) technology has the highest cost reduction potential among all renewable energy sources (RES). Although there have been rapid technological improvements, existing PV technologies nevertheless remain more costly than their traditional, non-renewable counterparts. In 2011 the global PV cell production increased up to $37 \mathrm{GW}$ and the $\mathrm{PV}$ cumulative installed capacities reached more than 67 GW. Since 2000, total PV production increased more than 125 fold, with annual growth rates between $40 \%$ and $80 \%$. The goal of increasing the use of PV energy is met with significant barriers. Market conditions for photovoltaic differ substantially from country to country. This is due to different energy policies and public support programs. Financing can also prove to be a barrier. Most PV markets are still dependent on public support in the form of feed-in tariffs, investment subsidies or tax-breaks and R\&D investments. Investors and potential adopters are challenged to find innovative ways to fund the construction of new plants or systems. Japan was dominating the PV industry business globally during the decade 1994 2004. During this period Japan PV market increased 46 fold. After 2005 Japan's PV market decreased and global cumulative installed PV share decreased from $30.5 \%$ in 2003 to $7.3 \%$ in 2011 . On the other side, since 2000 ,

*Address corresponding to these authors at the Graduate School of System and Information Engineering, Social System and Management, Tsukuba University, 1-1-1, Tennodai, Tsukuba, Ibaraki, Japan; Tel: +81-29-853-7291; Fax: ++81 29853 4922; E-mails: sanjeeda.chowdhury@yahoo.com, sumita@sk.tsukuba.ac.jp
German PV market increased abruptly. During 20002011, German cumulative installed PV market increased 196 fold from $126 \mathrm{MW}$ in 2000 to $24.7 \mathrm{GW}$ in 2011. The implementation of effective incentive mechanisms is clearly needed to increase the share of household participating in solar initiatives. Ongoing public and corporate research and development (R\&D) created the basis for this success. This paper presents a detailed analysis of public incentive and R\&D investments in solar PV investments over the last decades in Japan and Germany. The purpose of the present work is an analysis of public PV installation incentive/subsidy and R\&D investments during 19902011 and a critical discussion whether the level of these investments and the speed of their increase are sufficient for smooth PV deployment.

\section{METHODOLOGY}

In this paper, we survey actual market-based incentive mechanisms and R\&D investments of solar PV in Japan and Germany during 1990-2011. The key characteristics of incentive programs and $R \& D$ investments within each country are described, along with market outcomes. We undertake an empirical evaluation, comparing the key dates of programs in each country with changes in PV energy market share and net capacity. The declining factors of Japanese PV business during 2004-2008 were also discussed. This evaluation provides some indicative insight into the effectiveness of incentive programs and $R \& D$ investments. 


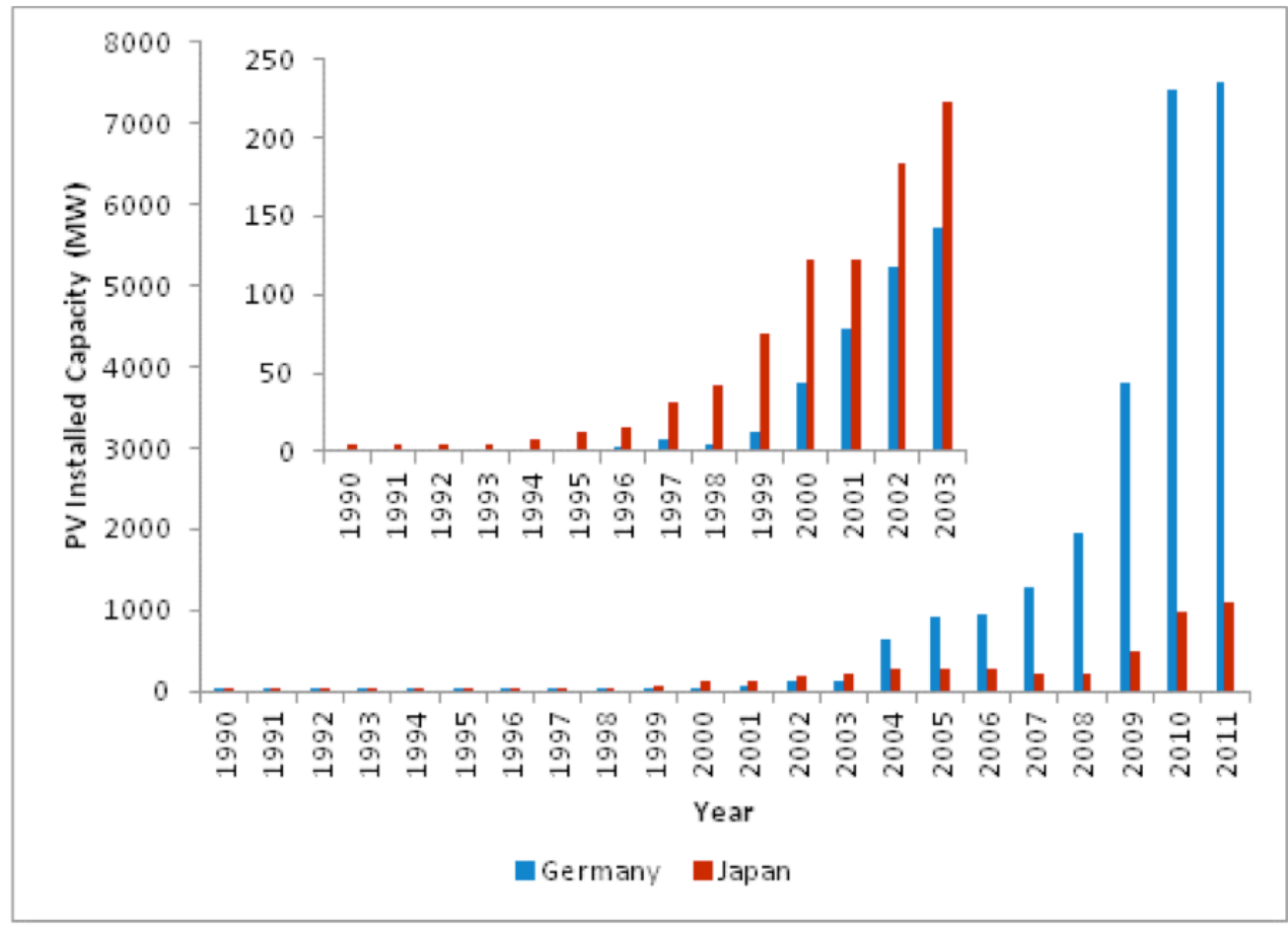

Figure 1: Development of Japan and German PV market, 1990-2011.

\section{RESULT AND DISCUSSION}

\subsection{PV diffusion in Japan and Germany}

Figure 1 shows the development of PV market in Japan and Germany from 1990-2011 [1-12]. Figure 2 shows world cumulative installed PV share in Japan and Germany, 2000-2011 [1-12]. Japan was dominating the PV market globally during the decade 1994 2004. During this period Japan PV market increased 41 fold from $7 \mathrm{MW}$ in 1994 to $290 \mathrm{MW}$ in 2005 [1-4]. After 2005 Japan's PV market decreased and became $210 \mathrm{MW}$ in 2007 and world cumulative installed PV share decreased from $30.5 \%$ in 2003 to $7.3 \%$ in 2011. On the other side, from 1990 to1999 German PV market did not grew at all but after 2000 it increased rapidly [5-12]. Since 2000, German PV market increased abruptly and it increased from 44MW in 2000 to $7500 \mathrm{MW}$ in 2011. Global PV production share of Germany increased from $8.8 \%$ in 2000 to $36 \%$ in 2011. During 2000-2011, development of German cumulative installed PV market increased 196 fold from $126 \mathrm{MW}$ in 2000 to $24.7 \mathrm{GW}$ in 2011. Whereas between 2000 and 2011, Japanese cumulative installed PV

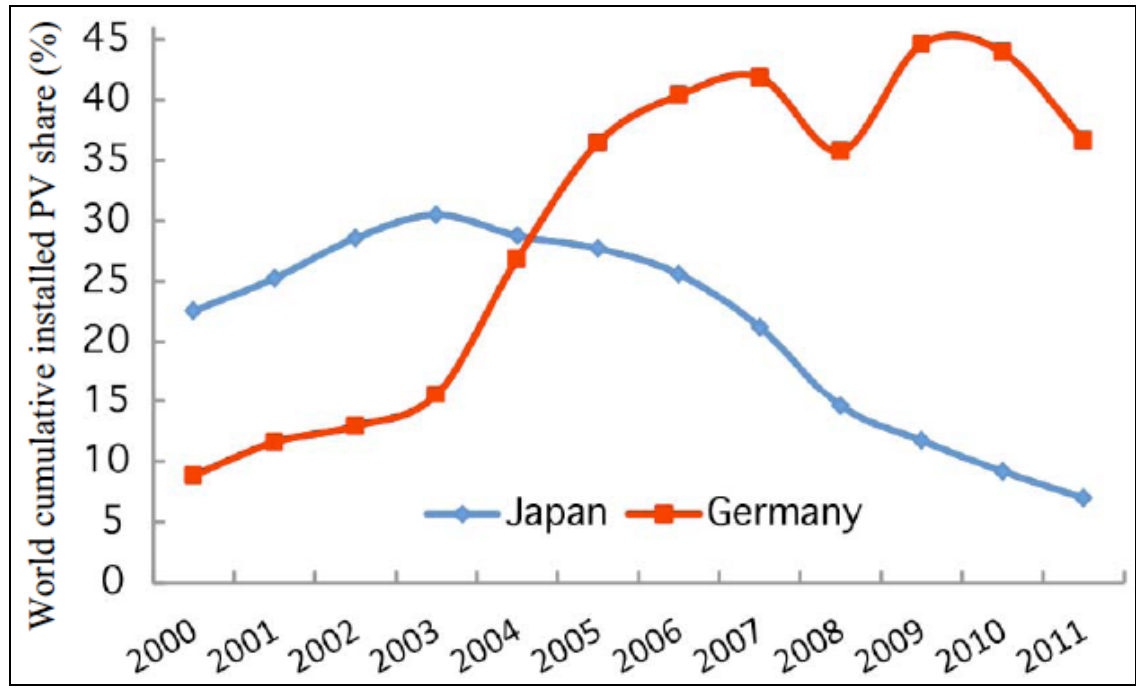

Figure 2: World cumulative installed PV share in Japan and Germany, 2000-2009. 
market increased only 15 fold from $322 \mathrm{MW}$ in 2000 to 4.9GW in 2011. The Japanese market has stabilized at around 290MW/year in 2005, while the German market is increasing and exceeds $7.5 \mathrm{GW} /$ year in 2011. Recently, Japanese PV market is increasing again from 2009 and exceeds $1 \mathrm{GW} /$ year in 2011.

\subsection{Market-Based Incentive and their Impact on the Diffusion Process of PV}

Both Japan and Germany have implemented a variety of market-based incentive program since the late 1980s to become a key player in the growth of PV market. Table 1 summarize the market-based incentives, like PV installation subsidy/loan and feed-in tariff, and PV installed capacity of Japan and Germany from 1990-2011 to demonstrate gradual progression of PV market. Grants/subsidies and subsidized loans for PV installation programs are commonplace throughout the world, but the terms and conditions associated with them can vary significantly. Designing an effective feed-in tariff depends on (a) the way in which the level of remuneration is determined and (b) whether and how a tariff may change over time.

Buy-back system for the surplus PV power at the selling price has been implemented (net metering system) in Japan since 1992. During 1991-2005, a feed-in-tariff for the surplus PV power equivalent to the selling price (20-30 JPY/kWh) was offered which was below the supply cost of solar electricity. In 1993, "New

Table 1: Market-Based Incentives, Like PV Installation Subsidy/Loan and Feed-in Tariff, and PV Installed Capacity of Japan and Germany from 1991-2011

\begin{tabular}{|c|c|c|c|c|c|c|}
\hline \multirow[b]{2}{*}{$\begin{array}{l}\text { Fiscal } \\
\text { Year }\end{array}$} & \multicolumn{3}{|c|}{ Japan } & \multicolumn{3}{|c|}{ Germany } \\
\hline & $\begin{array}{c}\text { Subsidy (\%) } \\
\text { (Subsidy, } \\
\text { JPY/kW)) }\end{array}$ & $\begin{array}{c}\text { net-metering } \\
\text { program } \\
\text { [JPY/kWh] }\end{array}$ & $\begin{array}{c}\text { PV Installed } \\
\text { Capacity } \\
{[\mathrm{MW}]}\end{array}$ & $\begin{array}{l}\text { PV module } \\
\text { Installation } \\
\text { subsidy/loan, } \\
\text { Euro/kWp }\end{array}$ & $\begin{array}{c}\text { Feed-In Tariff } \\
\text { Rates } \\
\text { Euro/kWh }\end{array}$ & $\begin{array}{c}\text { PV Installed } \\
\text { Capacity } \\
\text { [MW] }\end{array}$ \\
\hline 1991 & & 22 & 4 & $70 \%$ & 0.1661 & 1 \\
\hline 1992 & & 22 & 4 & $70 \%$ & 0.1653 & 1 \\
\hline 1993 & & 30 & 5 & $70 \%$ & 0.1657 & 1 \\
\hline 1994 & $50 \%(900,000)$ & 30 & 7 & $70 \%$ & 0.1693 & 1 \\
\hline 1995 & $50 \%(850,000)$ & 32.4 & 12 & $70 \%$ & 0.1728 & 2 \\
\hline 1996 & $50 \%(500,000)$ & 31.2 & 16 & & 0.1721 & 3 \\
\hline 1997 & $\begin{array}{c}33 \% \\
(340,000)\end{array}$ & 25.2 & 32 & & 0.1715 & 7 \\
\hline 1998 & $\begin{array}{c}33 \% \\
(329,000)\end{array}$ & 23 & 42 & & 0.1679 & 5 \\
\hline 1999 & $\begin{array}{c}33 \% \\
(329,000)\end{array}$ & 25.2 & 75 & $3115-6230$ & 0.1652 & 12 \\
\hline 2000 & $\begin{array}{c}33 \% \\
(270,000)\end{array}$ & 25.2 & 122 & $3115-6230$ & 0.574 & 44 \\
\hline 2001 & $13 \%(120,000)$ & 23 & 123 & $3115-6230$ & 0.574 & 78 \\
\hline 2002 & $13 \%(100,000)$ & 20.4 & 184 & $3115-6230$ & 0.574 & 118 \\
\hline 2003 & 90,000 & 23.5 & 223 & $3115-6230$ & 0.574 & 143 \\
\hline 2004 & $7 \%(45,000)$ & 24 & 272 & $3115-6230$ & 0.574 & 635 \\
\hline 2005 & 20,000 & 30 & 290 & & 0.5453 & 906 \\
\hline 2006 & nil & nil & 287 & & 0.518 & 951 \\
\hline 2007 & nil & nil & 210 & & 0.4921 & 1274 \\
\hline 2008 & nil & nil & 225 & & 0.4675 & 1955 \\
\hline 2009 & 70,000 & 48 & 483 & & 0.4301 & 3799 \\
\hline 2010 & 70,000 & 48 & 991 & & 0.3405 & 7411 \\
\hline 2011 & 48,000 & 48 & 1100 & & 0.2874 & 7500 \\
\hline
\end{tabular}


Sunshine Project" an effort to create a Japanese solar photovoltaic industry and a domestic market for solar power was initiated. Installations of residential PV systems, in Japan, have been rapidly increasing since 1994 due to the public subsidy from "New Sunshine Project" and the net-metering system provided by electric power companies. This project funded the installations of over $1100 \mathrm{MW}$ from 1992 to 2004. One reason Japan achieved this solar prominence can be attributed to the uninterrupted federal assistance. As shown in Figure $\mathbf{1}$ and Table $\mathbf{1}$, the Japanese PV market decreased after the incentive program and the net metering system was eliminated in 2005. During 2006-2008, PV installation in Japan gradually decreased and became $210 \mathrm{MW}$ in 2007 due to end of subsidy program. World cumulative installed PV share of Japan decreased from $30.5 \%$ in 2003 to $14.5 \%$ in 2008.

Recently, the Japan government has budgeted 20 billion yen for a 700,000 yen/kW PV installation subsidy available through 2009. Since 2009, PV installation increasing again due to new PV generated electricity purchase system, subsidy for new PV system installation and Feed-in Tariff Law [13]. A feed-in-tariff for the surplus PV power equivalent to the supply cost of solar electricity (48 JPY/kWh) was offered. In addition, in 2009, the government has provided several hundred million dollars over the past two years to subsidize installation costs for non-residential solar (1/3 of project costs for the commercial sector, $1 / 2$ for the public sector). So far $94 \%$ of the PV installed in Japan is grid-connected residential PV systems with governmental subsidies. Very recently, the government implemented a new feed-in tariff for solar electricity production that is expected to dramatically increase solar energy adoption [13].

During 1990-2000, a fixed feed-in-tariff rate of $€ 0.16$ $/ \mathrm{kWh}$ (total budget 3.5 M Euro) was offered which was below the supply cost of solar electricity [5-7, 14]. During the 1990s, a public subsidy of $70 \%$ installation cost for a solar roof program (1991-95) resulted in 2250 installations, representing approximately $5 \mathrm{MW}$ of installed capacity were of greater value promoting PV market. $50 \%$ of the investment costs under this scheme were funded by federal government, with a further $20 \%$ from regional governments. Until 1999, as shown in Table $\mathbf{1}$ and Figure 1, installations of residential PV systems in Germany were increased slowly. From 1999, PV installations increased rapidly under subsidy program of 100,000 roofs and Erneuerbare-EnergienGesetz (EEG). Reduced interest loans totaling $€ 695$ million were offered by the federal government's banking institutions for a 100,000 PV roof installation program between 1999 and 2003. As recent as 2000, the German PV market had only installed $40 \mathrm{MW}$ of solar. However, the catalyst to Germany's rise to prominence within solar power was the replacement of the 1990 FIT by the 'Erneuerbare-Energien-Gesetz' (EEG) in 2000. The 2000 version of the EEG implemented fixed, stepped tariffs, in which the rates were differentiated according to the solar producer's costs, market-responsive incentive levels and increased accessibility, rather than longer tied to the spot price of electricity. Tariffs set based on detailed predictions of project costs to cover solar installation plus a reasonable profit. Total participation and the size of eligible systems were also uncapped, creating opportunities for many types of market participants. The EEG also introduced tariff degression rates, based on theoretical models of technology learning. The biggest benefactor of this new FIT was solar energy, with PV electricity receiving $€ 0.57 / \mathrm{kWh}$ fed. Amendments to the EEG FIT in 2004 offered even greater levels of compensation for solar power, including $€ 0.57 / \mathrm{kWh}$ for solar electricity from small rooftop systems and an increase in annual degression fees for PV energy to $5 \%$. As a result, development of German PV market increased from 143MW in 2003 to $635 \mathrm{MW}$ in 2004 and $950 \mathrm{MW}$ in 2006. The EEG has required utilities to purchase PV energy from anyone willing to supply it. Remuneration varies by plant size and energy source, and rates are guaranteed to new system owners for a period of 20 years. Each type of owner is allowed to recoup their up-front costs and make a reasonable return on investment of $4-5 \%$ after tax. Tariffs decline annually based upon the market's response, with the cost shared equally among all ratepayers. The remuneration of solar electricity for PV modules installed in $\mathbf{2 0 0 6}$ was almost ten times higher than the market price of conventionally produced electricity. In January 2009, Germany introduced the $\mathrm{KfW}$-"standard" program offers loans for electricity from solar PV [14].

Stronger support for a potential correlation between the launch and refreshing of FITs and the growth in market share for electricity from solar energy sources can be found in Germany. In Germany, single-digit market share growth throughout the 1990s prompted by a combination of grants, loans, subsidies and a FIT was eclipsed by a higher level of annual growth after the 'Erneuerbare-Energien-Gesetz' (EEG) tariff in and 2004 revision. 
In German Feed-in-tariff, solar electricity is exclusively fed into the grid. Whereas in Japan, solar electricity is used for own consumption first, only excess electricity is fed into the grid. A closer comparison of solar PV in Germany and Japan also suggests that market-based FITs were more effective at driving net capacity growth than tax incentives, net metering system and fixed FIT. Figure 2 illustrates that the pivotal year for solar PV in Germany was 2004, when their EEG FIT of 2000 was revised to offer higher levels of compensation, including for solar electricity from small roof-top systems and an increase in annual degression fees for PV energy to 5\%. During 20002008, development of German PV market increased 42 fold from 126MW in 2000 to $5.3 \mathrm{GW}$ in 2008.

German residential PV installation continuously increased under stable and modified EEG program in form of a Feed-in-tariff (FIT). Germany Feed-in-tariff policy was very generous and it helped Germany to reach the world's top position with in a very short time (Figure 2). One of the benefits of the German FIT is that it provides economic incentives for end-use customers to buy PV systems. In this way, the market is greatly expanded from those who buy PV out of reasons of environmental consciousness to those interested in investment possibilities, thus also increase 'legitimacy'.

In Japan, the voluntary program for net-metering and buy-back of excess electricity from PV induces the 'formation of markets', and was very important for the formation of the grid-connected rooftop market. This market has been the most important one for PV in Japan during the last years. However, a difference between the net-metering system in Japan and the FIT system in Germany is that it does not provide enough economic incentives to make a PV system economically viable; electricity generated from a typical household PV system is twice as expensive as that bought from the grid. Another available support system, the RPS system (Renewables Portfolio Standard), does not seem to function to induce market formation either. The combined power of the Japanese support measures do not provide financial incentives for buying a PV, hence people buy PV for "emotional" reasons. 'The residential dissemination program', though very successful for creating a market, was not connected to goals for actual PV diffusion.

From the Japanese and German's incentives program we can say that Japanese sunshine project was a very good incentive program, it helped the
Japanese PV business to flourish, but after 2003 the market share decreased and at the end Japan lost its position and reputation. On the other side, in Germany the policy Feed-in tariff started from 1991 and is still working on for the PV business in Germany. The incentive program is also helping the consumers to make the system affordable to them. As shown in Figure 2, during 2003-2011, Japan global PV market share decrease from $30.5 \%$ in 2003 to $11.7 \%$ in 2009 . On the other side, German PV market share markedly increase from $15 \%$ in 2003 to $45 \%$ in 2009 .

\subsection{Research and Development Investment}

$R \& D$ is necessary to reduce the cost and improve the performance of $\mathrm{PV}$ technologies in order to make them more competitive with conventional energy sources. Research and development investment to buy down the price of solar power and performance improvements could help a nation retain its status as a leading global producer of solar technology. To provide insight into the political will to switch to sustainable energy production and use, especially PV energy, we reviewed the government R\&D support and also compare R\&D expenditures for PV to nuclear power of Japan and German.

Japan has had an active nuclear power program since nuclear research began in the country in 1954 . Nuclear energy figures prominently into Japan's national electricity mix. Japan currently has 53 nuclear power plants in operation with a total generating capacity of $46 \mathrm{GW}$ [15]. Nuclear power currently represents 18 percent of the country's total electric capacity and provides 30 percent of the country's electricity generation. Japan's level of renewable energy $R \& D$ investment has remained relatively constant over the past ten years (Figure 3) [16]. The majority of public funds for energy R\&D went to nuclear power, which received about $70 \%$ of the total. On the other side, in Germany, public R\&D funds for nuclear energy was $60 \%$ in 1990 which was continuously decreased and become $40 \%$ in 2010 . The review of public R\&D budgets shows that Japan's expenditures for PV amount to approximately $\$ 1.0$ billion in 2000 , which is an account for only $3 \%$, the total energy $R \& D$ investment. During 2001-2006, Japan's expenditures for PV increased little but again decrease during 2006 to 2010. Alternately, in Germany, renewable energy R\&D expenditures continuously increased during 1990 - 2010, which was $18 \%$ in 1990 and increased to $38 \%$ in 2010. Germany's expenditure for PV has remained relatively constant over the past ten years which 


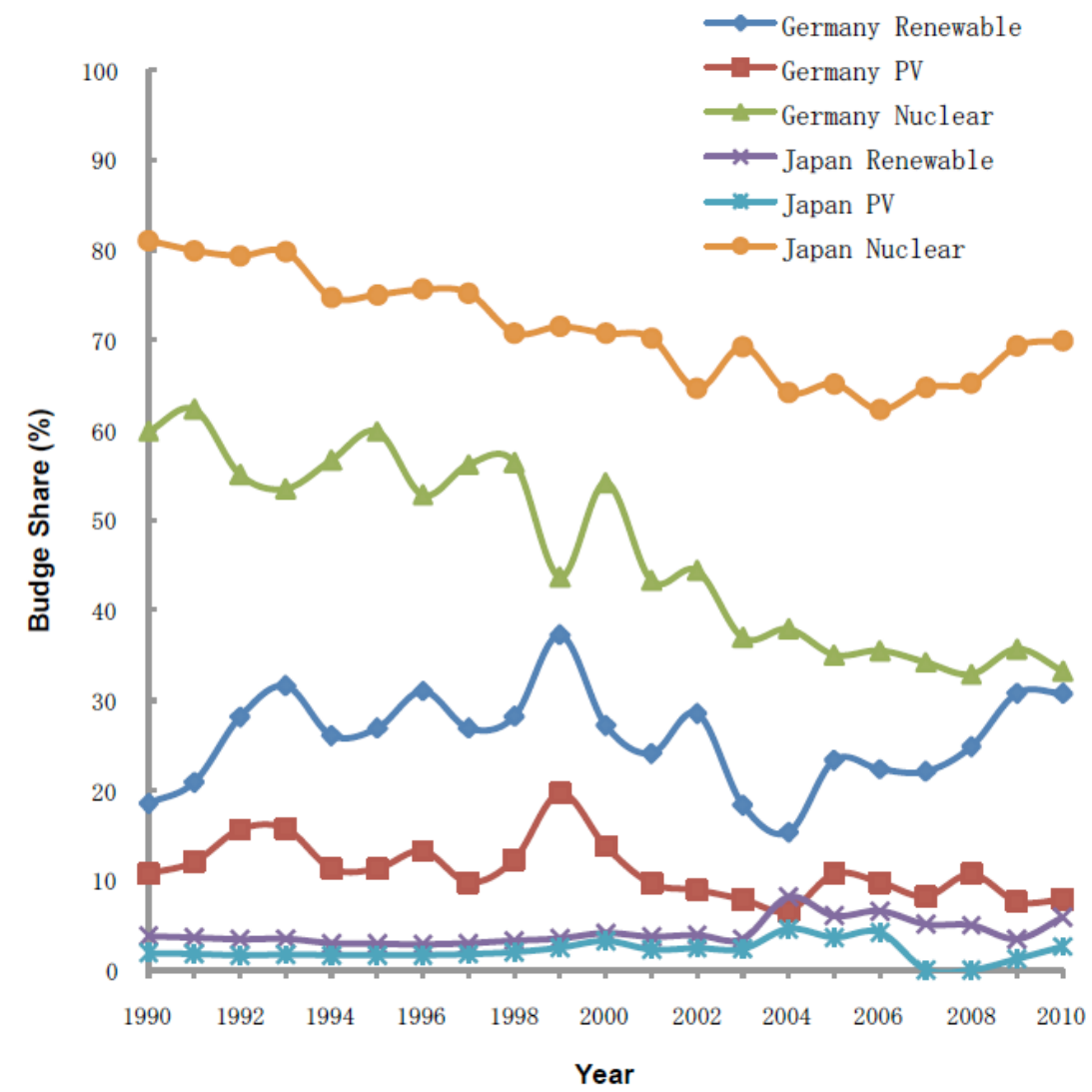

Figure 3: Government R\&D expenditures for PV, renewable, and nuclear power of Japan and Germany.

received about $10 \%$ of the total. With respect to public R\&D budgets on renewable energy as well as PV, Germany stands out Japan. Germany is vigorously developing a domestic as well as an export market for PV. Germany performs high with regard to R\&D spending and also host manufacturers of PV cells or panels and enable market growth for PV. Public R\&D expenditures are generally a minor fraction of the GDP. The only exception seems to be nuclear R\&D in Japan, which accounts for $0.6 \%$ of its GDP. This is about seven times higher than the corresponding figure for Germany. It is noteworthy; however, that nuclear R\&D in Germany is declining, whereas R\&D budgets for, renewable energy as well as $\mathrm{PV}$ are increasing. Summarizing, it is concluded that German public R\&D programs for renewable energy tend to be linked to the envisioned position of clean energy and to a lesser extent- in nuclear power generation.

\section{CONCLUSIONS}

Japan pioneered in solar PV technology only, whereas deployment for this technology shifts to Germany. A comprehensive strategy to lead the solar energy race must also include investment to develop domestic manufacturing capacity, as well as to create domestic market demand for solar product. The comparative study between Japan and Germany shows that the causes behind the declining factor of the PV market in Japan is the insufficient incentives to create domestic market demand and also public R\&D investment for PV energy tend to be linked to the envisioned position of nuclear power generation and -to a lesser extent- in PV energy. Market-based FITs have greatest impact upon the PV diffusion in Germany, although they are usually complemented by other forms of incentive such as grants/subsidies, loans or even tax incentives.

Increases in net capacity growth for electricity generated from solar PV appear to more closely correspond to FIT legislation than any other forms of incentive. Market-based feet-in tariff system can ensure long-term financial incentive for customers, a system that has proven successful in Germany.

\section{REFERENCES}

[1] Izumi K. Current status and future prospects of Grid Connected PV systems in Japan. UFTP \& IEA-PVPS Workshop, 16th February 2011, Istanbul, Turkey , RTS Corporation. http://www.iea-pvps.org/index. php?id=3\&elD= dam_frontend_push\&docID $=450$ 
[2] International Energy Agency. Trends in Photovoltaic applications: Survey of Selected IEA countries between 1993 and 2004. IEA PVPS, 2005. http://www.risoe.dk/rispubl/ $\mathrm{NEl} /$ nei-dk-4727.pdf

[3] Hiroyuki Y, Osamu I. National Survey Report of PV Power Applications in Japan 2011. Japan National Photovoltaics Status Report 2011, May 31, 2012. http://thesolarfuture.squarespace.com/storage/pictures-top10s/top-10-biggest-markets-2011/nsr_2011_JPN.pdf

[4] Masamichi Y. Osamu I. National Survey Report of PV Power Applications in Japan 2010. International Energy Agency, June 17, 2011. http://esci-ksp.org/wp/wp-content/uploads/ 2012/05/National-Survey-Report-of-PV-Power-Applicationsin-Japan.pdf

[5] Gerhard SH. Development of the Photovoltaic Industry in Germany. BSW-Solar, German American Chambers of Commerce 4th Germany California Solar Day, May 27th, 2008, San Francisco. http://www.wind-works.org/FeedLaws/ Germany/Stryi-Hipp_-_Development_of_the_PV_Industry_ in_Germany.pdf

[6] Matthias R. Renewables made in Germany, Political Conditions, Incentives and Market Development. Minneapolis, April 25, 2007 German Energy Agency, DENA, $2007 . \quad$ http://www.gaccom.org/fileadmin/ahk_chicago/ Dokumente/Matthias_Raab_German_Energy_Agency_05.pd

[7] Gerhard SH. PV Industry and Market Development in Germany: Status and Perspectives. BSW-Solar, 2007; Photovoltaics from Germany, 15 May 2007. http://www.sgc.org.sg/fileadmin/ahk_singapur/Energies/R_D_ and_PV_in_Germany_-_Gerhard_Stryi-Hipp.pdf

[8] Thomas C. Photovoltaics in Germany -Market Development and Perspectives. May 18th, 2010, New Jersey, USA. BSW-
Solar. http://www.gaccny.com/fileadmin/ahk_gaccny/ Dokumente/Marketing/Greenteam/Thomas_Chrometzka__BSW_01.pdf

[9] Lothar W. National Survey Report of PV Power Applications in Germany 2010. Germany National Photovoltaics Status Report 2011. http://www.iea-pvps.org/

[10] Statistic data on the German solar power (photovoltaic) industry. German Solar Industry Association (BSW-Solar) June 2011. http://www.photovoltaique.info/IMG/pdf/factsheet pv_engl.pdf

[11] Statistic data on the German solar power (photovoltaic) industry. German Solar Industry Association (BSW-Solar) June 2012. http://www.solarwirtschaft.de/fileadmin/media/pdf/ BSW_facts_solarpower_en.pdf

[12] Development of renewable energy sources in Germany 2010. July 2012, Renewable Energy-Statistics (AGEE-Stat). http://www.bmu.de/english/renewable_energy/downloads/do c/39831.php

[13] Market Implementation of Photovoltaics. PV Status Report 2011. http://re.jrc.ec.europa.eu/refsys/; doi 10.2788/87966

[14] Fulton $M$, Nils $M$. The German Feed-in Tariff for PV: Managing Volume Success with Price Response. DBCCA, May 23, 2011. https://www.dbadvisors.com/content/_media/ DBCCA_German_FIT_for_PV_0511.pdf

[15] Japan Energy Data, Statistics and Analysis - Oil, Gas, Electricity, Coal. http://www.arcticgas.gov/sites/default/files/ documents/11-03-eia-japan-energy.pdf

[16] IEA R\&D data 1990-2010 PV. http://www.iea.org/stats/ index.asp 